WeLls, A. Q. (1953). J. gen. Microbiol. 9, 149.

\title{
Mycobacterium tuberculosis var. muris
}

\author{
By A. Q. WELLS \\ Sir William Dunn School of Pathology, University of Oxford
}

SUMMARY: The valid name for the acid-fast bacillus which causes tuberculosis in voles is Mycobacterium tuberculosis var. muris Brooke.

The object of this paper is to discuss briefly the name for the mycobacterium which causes tuberculosis in voles (Wells, 1937), a full description of which has already been published (Wells, 1946). The mycobacterium has been called the vole acid-fast bacillus (Wells \& Brooke, 1940); the murine type of tubercle bacillus (Wells, 1946); Mycobacterium muris (Topley \& Wilson's Principles, 1946) and Myco.tuberculosis var. muris (Brooke, 1941). The name Myco. muris has already been given to a mycobacterium isolated by Simmons (1927) from the intestinal contents of a house mouse. His description of the cultural requirements and pathogenicity of this bacterium clearly shows that it is quite different from the mycobacterium isolated from voles. The name Myco. muris is not therefore available for the latter.

It is not necessary to recapitulate the details of the experimental work already published (Wells, 1946), which lead to the conclusion that the bacterium causing tuberculosis in voles is a new type of tubercle bacillus. If this work is accepted, the proper name for the mycobacterium would seem to be Mycobacterium tuberculosis var. muris Brooke.

\section{REFERENCES}

Brooke, W. S. (1941). The vole acid-fast bacillus. Amer. Rev. Tuberc. 43, 806.

Srmmons, J. S. (1927). An acid-fast organism isolated from a mouse. J. infect. Dis. 41, 18.

Topley and Wilson's Principles of Bacteriology and Immunity (1946). 3rd ed. revised by Wilson, G. S. \& Miles, A. A. London: Arnold.

WeLls, A. Q. (1937). Tuberculosis in wild voles. Lancet, i, 1221.

Wells, A. Q. \& Brooke, W. S. (1940). The effect of vaccination of guinea-pigs with the vole acid-fast bacillus on subsequent tuberculous infection. Brit. J. exp. Path. 21, 104.

WeLrs, A. Q. (1946). The murine type of tubercle bacillus (The vole acid-fast bacillus). Spec. Rep. Ser. med. Res. Coun., Lond. no. 259.

(Received 20 March 1953) 